During the Great War, the periodical meetings of the International Association of Academies and of many other international organizations could not be held, though some of them were continued in neutral countries. In 1918, therefore, the Royal Society, the Academy of Sciences, Paris, and the National Academy of Sciences, Washington, discussed informally the question of the future organization of the scientific undertakings which had been carried on before the War by international co-operation; and ultimately the academies of all the allied countries were invited to send representatives to a conference which took place at the rooms of the Royal Society in October 1918. This was followed by a meeting at Paris at the end of November, when it was agreed to form an International Research Council and a number of affiliated International Unions to deal with matters of international scientific interest, which was done at Brussels in the next year.

Besides the ordinary routine of the triennial meeting, which is being held in London on April 26May 4, the Council will have for consideration the report of the standing committee on the Study of Solar and Terrestrial Phenomena, and also that of the committee which was appointed three years ago to report on the relations which should exist between the Council and the Committee of Intellectual Co-operation of the League of Nations concerning matters of international science.
The Royal Academy of Amsterdam is proposing that the International Council should appoint a committee to study what co-ordination can be achieved in the opinions which have been put forward regarding the social responsibilities of science and of scientific workers towards the dangers at present menacing the future of civilization.

Public lectures will be given on April 28 and April 30 at the Royal Institution; the former by Sir William Bragg, on "Classical Experiments made at the Royal Institution", and the latter by Prof. E. V. Appleton, on "International Cooperation in Radio Research". The Government is giving an evening reception to the delegates at Lancaster House on April 29.

Arrangements have been made for the delegates to visit a large number of scientific institutions in and near London, where they will receive assistance from members of the scientific staffs in the objects of their visits.

The General Assembly will hold its closing meet. ing on Monday, May 3, and the delegates will attend the soirée of the Royal Society on Tuesday, May 4.

On Tuesday, April 27, there will be a reception of the delegates at the University of London, when the Chancellor of the University, the Earl of Athlone, will confer the honorary doctorate of science on Dr. N. E. Nörlund, the president of the International Council.

\title{
The Total Solar Eclipse of June 1937
}

$\mathrm{T}$ HE total eclipse which starts on June 9 next and, crossing the date line, ends on June 8, will be the longest visible for many years, the maximum duration of totality being 7 minutes 4 seconds. It is most unfortunate that the belt of totality lies almost entirely over the ocean and that the maximum duration available from land is reduced to 4 minutes 8 seconds. This is from Enderbury Island in the Phoenix Group (lat. $3^{\circ} 8 \cdot 5^{\prime} \mathrm{S}$., long. $171^{\circ} 10 \cdot 0^{\prime} \mathrm{W}$.) which is described in the Sailing Directions, Pacific Islands Pilot, vol. 2, 1932, as " 30 feet high, uninhabited and surrounded by a coral reef, which is steep to. There is no fresh water, no anchorage and landing is difficult". The island is about 2.5 miles long and 1 mile wide. Of the other islands in the Phoenix Group, which lie within the belt of totality - Gardner, McKean, Hall, Birnie, Canton and Phoenix, all uninhabited - the most suitable island for landing eclipse apparatus appears to be Canton Island (lat. $2^{\circ} 28 \cdot 9^{\prime}$ S., long. $171^{\circ} 42 \cdot 6^{\prime}$ W.).
Here totality lasts 3 minutes 45 seconds. The island is a coral atoll 10-12 feet high, with a spacious lagoon : there is anchorage, in 10 fathoms, unsafe with westerly winds, close to an entrance to the lagoon on the west side. Coco-nuts have been planted on the island, which is nine miles long by four miles wide. The islands are leased by the Colonial Office to Messrs. Burns Philp (South Seas) Co. Ltd., and come under the jurisdiction of H.E. the High Commissioner for the Western Pacific at Suva, Fiji.

The belt of totality east of the Phoenix group never strikes land until at sunset it reaches the coast of Peru. The U.S. Navy reported an island, Sarah Anne Island, which would have lain in the track of the shadow, but the island must have sunk below the ocean as it is no longer to be found. In Peru the maximum altitude of the sun is $8^{\circ}$ and the maximum duration of totality 3 minutes 20 seconds. The Faculty of Science of the University of San Marcos has formed a 
committee to help visiting scientific expeditions in all matters of transport, meteorology, health conditions and camp installation. The Dean of the Faculty, Prof. Godofrich Garcia, is president of the Committee.

So far, three expeditions have been announced as going to observe this eclipse. With the aid of a sloop of the New Zealand Navy, Mr. C. B. Michie, of Kaitaia, N.Z., is taking a party consisting of Dr. W. C. Burns and Mr. F. Gawithall three being members of the 1930 expedition to Niaufou' or Tin-can Island-and Mr. Thomsen and some other member of the staff of the Dominion Observatory. The 19-foot coronagraph used at the eclipses of 1926, 1929, 1930, 1932, and 1936, has been sent to Mr. Michie from Japan and will be taken by him to Canton Island. By kind permission of the Royal Irish Academy, the 8-inch Grubb cœlostat will be used to feed the coronagraph. Photographs of the corona will, it is hoped, be secured through various colour-filters. Other details of the programme are not available here. Another party will be organized by the U.S. Nary, the National Geographic Society and the National Bureau of Standards, and will proceed to Canton or Enderbury Island. Prof. S. A. Mitchell, director of the Leander McCormick Observatory, will be the scientific leader of the expedition, while Captain J. F. Hellweg, Superintendent of the U.S. Naval Observatory, Washington, will be responsible for the naval side of the work. Dr. H. D. Curtis, director of the Ann Arbor Observatory, Michigan, Dr. P. A. McNally, director of the Georgetown College Observatory, Dr. F. K. Richtmyer, of Cornell University, Dr. I. C. Gardner, National Bureau of Standards and Mr. J. W. Willis, of the Naval Observatory, accompany the expedition and assure a wealth of valuable eclipse experience. The party will be completed by a naturalist (a naval surgeon), and a photographer from the National Geographic Society.

The spectrum of the chromosphere and corona will be photographed by Dr. Mitchell and Dr. Curtis respectively. Dr. MeNally will photograph the corona through a variety of filters, while Dr. Richtmyer will measure the total light of the corona. Colour photographs of the corona will be attempted by Dr. Gardner, who will repeat some of the photographs secured by him in Siberia last June (see Nature, March 13, p. 434). Time observations of contacts will be made by the observers from the Naval Observatory.

This party will be taken from Honolulu by the U.S. Navy mine-sweeper Avocet early in May. They may have a difficult time in preparing for the eclipse. We can only hope that the good weather, which has generally, though not invariably, attended Dr. Mitchell and Dr. Curtis, will hold for both parties on the morning of June 8 next.

A Japanese expedition, under the leadership of Prof. I. Yamamoto, of the Kwasan Observatory, Kyoto, will proceed to the coast of Peru to observe the eclipse of next June at sunset. The other members of the party are Prof. T. Araki and Messrs. Y. Sibata and M. Horii. The programme includes photography of the corona and of the spectra of the chromosphere and corona, photometry of the corona and some geodetic observations. The equipment will include some cinematograph cameras.

\section{Radium Treatment in Great Britain}

$\mathrm{R}^{2}$ ADIUM treatment is an established medical service in Great Britain, as may be gathered from the reports which are issued from year to year, especially by the four important organizations which have the responsibility of encouraging its practice and of helping research bearing upon its many problems. These organizations are the National Radium Commission, now in its eighth year of existence, and King Edward's Hospital Fund for London, both of which are primarily concerned with treatment; the British Empire Cancer Campaign and the Medical Research Council, whose interests in the subject are primarily research, their common matters of discussion in the first instance usually being referred to a joint
Radiology Committee. The allocation of radium by these four organizations at present exceeds 40 grams of radium element.

The seventh annual report of the Radium Commission* includes a statistical report of 47 pages which teems with interest. It being no longer a question whether radium is of any use in the treatment of cancer, one of the first questions which the Commission has tried to answer is how much use it is. To this end, an elaborate plan was laid, and the first fruits of this are now at hand. The present report gives the 3-year and 5-year results of radium treatment of five common

* Seventh Annual Reports of the National Radium Trust and Radium Commission 1935-1936 including a Statistical Report. (Cmd. 5342.) Pp. 91. (London: H.M. Stationery Office, 1937.) 18. 6d. net. 